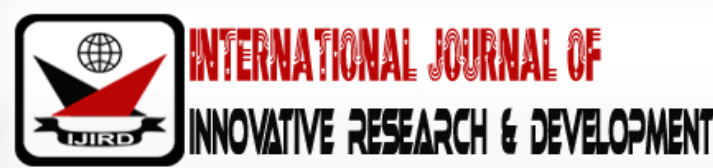

ISSN 2278 - 0211 (Online)

\section{The Nigerian Industrial Landscape and Environmental Degradation}

\author{
Dr. Okhakhu Poly Alens \\ Senior Lecturer, Department of Geography and Environmental Management, \\ Ambrose Alli University, Ekpoma, Nigeria
}

\begin{abstract}
:
This study examines the Nigerian industrial landscape and environmental degradation. It uses the spatio-temporal approach to analyze the sequential development of the Nigerian industrial landscape. Based on authentic first-hand data obtained from the four major industrial zones in Nigeria and relevant industrial literature, the study analyzes the different forms of industrial-induced environmental degradation which span the physical surfaces, fertile soils, vegetal, water and atmospheric resources with adverse impacts on the sustainability of Nigeria. It identifies the industrial establishment factors in Nigeria as physical surface, raw materials, working capital, technology, transport, energy supply, domestic labour, skilled management, workplace security, market performance, storage facilities, climate, and paid allowances. Of these relevant factors, only the physical surface and climate exist in adequate standard. These led to inadequate results-oriented industrial operations in Nigeria. Based on the findings, secure workplace environments, sufficient capital, suitable tropical raw materials, digital technologies, effective transport and communications, viable markets, stable energies and trained management should be provided by the three tiers of government in mutual association with the private sector to ensure results-inclined industrial operations in Nigeria. Above all, there should be sustained industrial wastes control, standard treatment and hygienic disposal at suitable sites and specialist clearance of crude oil spills and mining wastes from the land, vegetal and water surfaces to stem the persistent tides of industrial degradation and pollution of the Nigerian environment.
\end{abstract}

Keywords: Industrialization, development, environment, degradation, Nigeria

\section{Introduction and Research Problem}

Over the past four decades, many developing countries in the humid tropics of Africa including Nigeria have embarked on different schemes, patterns and policies of industrialization. This industrial option has been overwhelmingly considered as the immediate panacea to the sprawling intractable challenges of socio-economic development in these countries (Sullivan and Ikpeze, 1980). The expectation is that through industrialization, there would be adequate jobs for the people, national income and foreign earnings would improve, climate-resistant socio-economic infrastructures would be established on the surface, diverse manufactures would be displayed for sale in the markets, there would be spatial diffusion of technical and managerial skills among the established industries, and the overall standards of living of the Africans would be immensely ameliorated and sustained. Industrialization facilitates beneficial international trades among the different countries of the world. It enhances viable diplomatic relations among the trade-partners and ensures continuous exchange of significant technical, scientific and socio-economic inventions within the international community. However, the extent to which these fundamental industrial goals have not been achieved specifically in the humid tropical Nigeria has been discussed extensively by Adeboye (1981) and Oyebanji (1982) in their studies.

In this study, the term Industrialization refers to the process of economic transformation from a primary rudimentary pre-industrial existence to a realistically operational industrial state. It means the establishment of different types of industries in a demarcated place on the earth's surface. Rather than using the rudimentary and obsolete equipment in the production process as observed in the ancient and medieval epochs, the practical reality shifts directly to the utilization of manual and automated machinery in the production process at the industrial establishments where mass outputs are turned out. On this note, we define the Nigerian Industrial Landscape (NIL) as a huge composition of different units of firms set up on the environment with varying sizes of operational business interests which engage in the processing and refining of raw materials into finished products where standard scientific techniques and technologies are utilized. The sustained provision of socio-economic services to the people, the repairs and sustenance of industrial technologies, and the transportation of outputs 
through diverse networks for storage and to the points of human acquisition for various applications constitute the Industrial Landscape. More so, the NIL extends to incorporate the diverse sources and types of raw materials required for production, secure environment, operational capital, functional technologies, skilled management, vibrant workforce, robust markets for outputs acquisition, industrial impact assessments on the environment, scientific studies of environmental maintenance programs, implementation of vital findings of inventive industrial studies and future industrial sustainability in Nigeria. In addition, it encompasses authentic anticipation and predictions of industrial constraints development, the panaceas to resolve these challenges, and the future prospects of manufacturing establishments and other categories of industries in Nigeria.

Environmental degradation, in the current context, implies the deleterious transformation of the physical, chemical and biological properties of the natural environment into a state of virtual waste owing to deliberate introduction of dangerous substances such as toxic wastes, chemical fluids, agro-industrial garbage, crude oil spills and other diverse contaminants. It means the gradual break down and decay of the natural properties of the environment precipitated by unguided human activities. The concept connotes the deterioration, debasement, diminution or degeneration of the natural values of the environment induced by inadvertent and deliberate human-industrial deposition of waste materials, toxic chemicals and other dangerous substances.

One of the key spatial manifestations of the policy of industrial development in Nigeria which partly reflects and explains the failure, as Segynola (1986) observes, is the concentration of heavy manufacturing industries in four specific zones in the country. This implies that the other suitable vast portions of the country are devoid of these important industrial establishments. This spatial disparity of heavy industries in Nigeria was driven by three mutual factors: the economic policies of the colonial government; the faulty political dispensation of her past government which was deeply immersed in ethnic chauvinism; and the uneven availability of suitable factors which include raw materials, capital, skilled management, proximity to coastal ports and international markets, pristine climate, convenient environment, reliable transport and regional security. Founded on these significant socio-economic and technological factors, mining, power, electrical-electronics, metallurgical, agro-processing, pharmaceutical, construction, recreation, textiles and miscellaneous industries were established in the country.

Over the past decade and recently, the Nigerian industrial landscape has shown dismal results in the aspects of outputs production, jobs creation, infrastructure provisions, energy generation, and national income and foreign exchange attraction owing to prevalence of natural and human challenges. First, adequate capital and climate-resistant western technology are virtually limited to these manufacturing industries. Proficient human resources have drifted overseas owing to stagnant salaries and insecurity of human lives spurred by the Boko Haram insurgency in the North East, Middle Belt and some isolated pockets of settlements in the country. Second, adequate power supply which is required for technical operations and regular innovative scientific studies into industrial operations is virtually lacking in the landscape. The climate change impacts specifically high radiation and induced torrential rains which result to flooded surfaces of industrial establishments and inevitable collapse of vital buildings have restricted the maximum production of these heavy industries in Nigeria (Okhakhu, 2016). The Fulani herdsmen's anti-agricultural activities and their reckless killings of farmers have paralyzed the agricultural sector of the Nigerian industrial economy. Finally, these industrial landscapes have become the major areas of dense urban populations, inadequate infrastructures, limited jobs, political restiveness, crime evolutions, ritual atrocities, and immense environmental waste generation, distribution, deposition and deterioration which are currently cumbersome to manage by the different tiers of government, business organizations, and the private sector in Nigeria.

It is against this background that this current study examines the Nigerian industrial landscape and environmental degradation. The scientific focus is to assess the development of the Nigerian Industrial Landscape, analyze the four significant industrial zones in the country, and examine the different forms of environmental degradation observed in each of the four specific industrial zones identified in Nigeria.

\section{Research Materials and Methods}

This study proceeds from the empirical-inductive phase to the theoretical-deductive phase (Akinbode, 2004). This implies that the study starts from the known industrial activities which were physically observed using the reconnaissance surveys in the four major industrial zones identified in Nigeria. The empirical inductive phase sums up at the theoreticaldeductive phase where adequate consultation and review of the existing industrial literature were carried out with a view to expanding the frontiers of knowledge in spatial industrial studies. More so, the Collins' Advanced Atlas was used to identify the four major industrial zones in Nigeria (Collins, 2010). The exact locations, physical sites and the configurations of these heavy manufacturing industries in Nigeria have been examined in the previous studies (Segynola, 1986; Okhakhu, 2010; 2014). Most fundamentally, besides functioning as the vibrant urban and industrial centres in Nigeria today, Lagos, Abeokuta, Ibadan, Osogbo, Benin City, Sapele, Warri, Onitsha, Enugu, Owerri, Port Harcourt, Kano, Kaduna and Jos have, at different epochs, served as prominent ancient kingdoms, commercial, educational, cultural, recreational, tourist, and administrative towns and cities in the contemporary West African Region of Africa.

Randomly inclined reconnaissance and systematic surveys were carried out in the four major heavy manufacturing industrial zones in Nigeria. These structurally planned surveys were aimed at the acquisition of authentic first-hand data on large-scale industrial operations and performances based on significant spatial industrial establishment factors in Nigeria. The practising industrialists, workers in the industries, consumers of the industrial outputs, and the spatial industrial scientists 
with refined traits were the target respondents in the study. Of course, 1,200 structured questionnaires were systematically distributed and randomly administered to these respondents where each of the four major industrial zones in Nigeria received 300 questionnaires only. On the whole, 1,120 answered questionnaires were retrieved from the industrial fields, thereby producing $93.3 \%$ reliability level which was validly suitable for authentic scientific industrial analysis in Nigeria. The Nigerian postal system, contracted research assistants and field workers in adequate statistics played vital roles in making the industrial surveys a huge success.

The spatio-temporal approach was used to analyze the development of the Nigerian Industrial Landscape. The select spatial units were the coastal, forest, middle belt and the northern regions while the temporal epochs were the pre-colonial, the colonial, and the post-colonial. Above all, the cause-effect analysis was applied in the study. Based on the research findings, the prescriptive scientific approach was applied in realizing the policy recommendations.

\section{The Development of the Nigerian Industrial Landscape}

In analyzing the development of the contemporary industrial landscape in Nigeria, the spatio-temporal approach is suitable and this is adopted in the current study for easy scientific understanding. The chosen spatial units are the coastal, forest, middle belt and the northern regions while the selected periods are basically the pre-colonial, the colonial, and the postcolonial.

In the pre-colonial period, the traditional industries and crafts were widespread in the Nigerian industrial landscape. These traditional industries used natural raw materials which were derived from the thickly rich forests and related environments for diverse manufactures. Based specifically on the utilization of local raw materials for the classification of industries in Nigeria, we have three different types which are examined beneath.

First, we have the industries which process agricultural products into refined local food for human consumption. The agricultural products which are refined in this regard are yams, cassava, potatoes, plantains, pineapples, coconuts, cashew, cocoa and oil palms. Specifically, these important agro-products are produced in the huge coastal and forest regions of Southern Nigeria. The refined outputs of these industries are yam, cassava, potato and plantain flours, coconut and cashew cakes, coconut and pineapple juices, garri, cashew nuts, pineapple meals, and coconut, palm kernel and palm oils.

Second, there are the industrial establishments which are typically prominent in the processing of non-consumable food items by using agro-based raw materials derived from the richly fertile forests and immediate environment. Most of these local industries are established in the Southern Region and Middle Belt of Nigeria. These industries utilize raw materials such as palm trees, forest woods, ropes and gums for weaving baskets, making canoes, constructing make-shift huts and carving ornamental products. The cotton which is produced in the South of the country is also used by the industries to manufacture diverse textiles required for income generation through sales and human body protection during harsh and pristine weather in the country.

Finally, we have the industrial establishments which use valuable soil materials and iron scraps for making pottery, hoes and cutlasses, knives and spears, and related iron products in the Southern Region of Delta, Edo, Cross-River, Rivers, Osun, Ondo, Ekiti and Oyo States in Nigeria. The products of these industries have been found most significant in agricultural, recreation and environmental sanitation activities in the country. The three types of traditional and craft industries identified in the coastal, forest and middle belt regions of Nigeria were served by functional market centres which were established in the pre-colonial urban areas of Ibadan, Ile-Ife and Benin City situated in the South, and Kano, Sokoto, Katsina and Maiduguri located in the North.

During the colonial period up to 1951, industrialization in Nigeria was aimed at the valorization of export commodities. This strategy was meant to serve the colonial interest by providing essential raw materials derived from the rich forests and local plantations for the British industrial economy (Adegbola, 1978). By inference, ecologically, Nigeria as a British colony greatly complemented this country in Europe. Naturally, as Segynola (1986) observes, the cotton ginneries, leather tanneries, rubber, cocoa and oil palm processing industries had to be located in the most suitable ecological regions where the needed British industrial raw materials were produced. Of course, we can summarize that during the pre-colonial Nigerian existence, there occurred robust intensification of manufacturing activities in the different industrial zones identified in the study.

The post 1951 period of the Nigerian Industrial Landscape development witnessed the exportation of abundant raw materials overseas and the importation of few western manufactured products into Nigeria. This economic approach, as Segynola (1986) observes, greatly retarded the industrial development in Nigeria. The viable panacea devised by the Nigerian Government to resolve and reorder this adverse industrial scenario was the adoption of the import substitution strategy. This industrial option motivated the Nigerian industries to manufacture the needed goods which were hitherto manufactured in Britain and imported in exorbitant foreign currencies into Nigeria. However, since the Nigerian industries were grossly raw material oriented and virtually devoid of standard western technology and the needed human skills for efficient operations and adequate production of the required outputs, this import substitution strategy did not yield the anticipated industrial results. As Okafor (1983) assesses the situation, this strategy did not produce abundant results but it rather consolidated the organizational and spatial structures originally imposed by the old merchant firms and marketing boards in the preindependence Nigeria. 
In the contemporary post-independence epoch, Nigeria achieved fairly improved social, economic and political transformations fundamentally in the aspects of viable urban transportation, housing, health, communications, internet banking and marketing operations. Other factors were availability of capital and industrial technology, adequate warehouses, productive skilled labour and efficient management, stable governance, and pristine industrial environments. Based on these significant factors and their accessibility to and utilization in the industrial establishments, four basic industrial zones and some pockets of industrial establishments are identified currently in Nigeria. These are the Lagos-Abeokuta-Ibadan-Osogbo Zone; the Benin-Sapele-Warri Zone; the Kaduna-Kano-Jos Zone; and the Onitsha-Enugu-Owerri-Port Harcourt Zone. These specific four industrial zones are located in the Western, Mid-Western, Northern and Eastern Parts of Nigeria. Of course, in each of these industrial zones is located several functioning urban centres that are normally the viable site choices of most industries.

\section{The Four Major Manufacturing Industrial Zones in Nigeria}

\subsection{The Lagos-Abeokuta-Ibadan-Osogbo Industrial Zone}

The Lagos-Abeokuta-Ibadan-Osogbo industrial zone is the largest heavy manufacturing industrial region in Nigeria. The industrial zone occupies the coastal forest undulating south-west plains of Southern Nigeria. Of the total observed statistics of large-scale manufacturing industries in Nigeria from 1972-1977, 43.5\% were directly located in the south-west industrial zone (Obot, 1978). The figures for the distribution of industrial employees during the epoch also reveal that this zone has the greatest number. As shown by Adegbola (1978), Lagos State alone contained 38\% of all the industrial employees before and after the Nigerian civil war. From 1973-1998, the figures had risen to 50\%. As observed, the south-west industrial zone is habitat to a number of extractive, manufacturing and tertiary industries. The food, textiles, rubber, plastics, wood, petrochemical, metallurgical, pharmaceutical, electronics, and associated mixed industrial units are the most significant in this consideration.

\subsection{The Benin-Sapele-Warri Industrial Zone}

This industrial zone as shown in Figures 1 and 2 occupies the relatively undulating coastal and forest plains of the mid-west region of Southern Nigeria. The industrial zone comprises three important urban centres which are Benin City, Sapele and Warri in the contemporary Edo and Delta States in Nigeria. These urban centres, according to Sada (1984) and Omuta (1984), have shown considerable industrial development in recent time in Nigeria. In Benin City, there are viable primary and secondary industrial establishments. First, there are diverse saw-mills which process the natural trunks of tall trees into refined electric poles and wood materials for making significant furniture items like chairs, beds, shelves, stools and tables. These wood factories are also found in large-scale in Sapele, Delta State where they provide jobs and associated social services to the people. There is the Nigerian Brewery in Benin City which also renders beneficial socio-economic services to the residents. Second, in the Warri Industrial Zone which consists of Isoko, Ughelli, Warri, Bomadi and Burutu environs, there is extensive crude oil exploitation by a combination of local and multi-national industries. There are other industrial establishments which produce glass, plastic, textiles, roofing sheets and agro-products for direct human utilization. This is also one of the most significant industrial zones in Nigeria where adequate local and foreign currencies are generated for national accumulation, appropriation and utilization.

\subsection{The Kaduna-Kano-Jos Industrial Zone}

The Kaduna-Kano-Jos industrial zone occupies a suitably extensive environment of propulsive industrial activities in the Sudan north-central of Northern Nigeria. The zone is truly a symbolic live industrial triangle that was once analyzed in the industrial location theories postulated by Alfred Weber in 1909 and Renner George thereafter. Renner George, as Segynola (2010) argues, classified industries into four basic types which include the extractive, reproductive, fabricative and the facilitative establishments. In reality, Renner George considered the suitable location and establishment of propulsive industries as being largely determined by adequate land, raw materials, stable power, market, skilled management, transport, capital, subsidized taxation and agglomerative benefits of industrialization.

These significant industrial factors, based on ethnic political dispensation of the past regimes, are adequately at relative operation in this huge triangular industrial zone in Nigeria today. More so, the types of industrial establishments found in the zone accurately tally with the Renner George earlier industrial classification. Of all the industrial varieties currently operational in the zone, the Kaduna crude oil refinery and textiles mills are the largest in dimension. There are other important manufacturing industries at the Kano Bompai industrial estates which receive most of their raw materials from the local environment and few foreign locations in Niger, Mali, Egypt, Libya and Saudi Arabia. These industries manufacture textiles, plastics, roofing sheets, books, confectioneries and other miscellaneous products. Mining activities which incorporate tin and columbite extractions from the plateau surfaces and subterranean layers are regularly carried out in the Jos areas of the Industrial Triangle. As observed, this area receives the bulk of ecological degradation which impacts adversely on the immediate communities. 


\subsection{The Onitsha-Enugu-Owerri-Port Harcourt Industrial Zone}

This industrial zone is located in the south-east of Southern Nigeria. It occupies the coastal, forest and parts of the middle belt areas in Nigeria. It is one of the largest, productive and most successfully operational industrial zones in the country. It has many extractive, fabricative and crude oil refining industries in the country. More so, there are other productive plastic, asbestos, steel and iron manufacturing industrial establishments in this part of Nigeria. The zone has two large crude oil refineries, petrochemical industries and a huge natural liquefied gas plant in Boney-Island which produce fuel, diesel, kerosene, engine oil, acids, paints, chemicals, and other varieties of petroleum products for domestic and foreign utilizations. This zone in combination with the Benin-Sapele-Warri industrial zone produces the best quality crude oil, aviation and automobile fuels, kerosene, gas, diesel, chemicals and generates the highest local-foreign currencies for national accumulation, appropriation and utilization in the country.

\subsection{Pockets of Industrial Establishments in Nigeria}

In Nigeria, there exist 'some pockets of industrial establishments' outside of the four prominent industrial zones analyzed at the outset of the study. These pockets of industries are found in Okpella, Igarra, Ikpieshi and Iyuku in the northern part of Edo State, Ajaokuta and Okene in Kogi State, Nkalagu in Anambra State and Ewekoro in Ogun State. Other industrial islands are available in Sokoto in Sokoto State, Ilorin in Kwara State, Calabar in Cross-River State, Potiskum in Yobe State and Maiduguri in Borno State. The types of industries which are found in the four cardinal belts in Nigeria are involved in the processing of limestone into cements, cocoa into bournvita, animal hides and skins into bags, shoes, caps, belts and ropes, cotton into textiles, and iron-ore into different iron railings and related iron products. In standard classification, these pockets of industries are essentially primary, secondary and tertiary natured. Of course, the creation of jobs, revenue generation, market establishment, construction of infrastructure, and production of food for human consumption represent some significant functions of these islands of industries in Nigeria. As observed in the field surveys, these pockets of industries are found in the coastal, forest, middle belt, and northern parts of Nigeria.

Tables 1 and 2 show the required industrial establishment factors as obtained from the authentic responses of the respondents in the four major heavy industrial zones in Nigeria. The respondents are the workers in the industries, the industrialists, consumers of the industrial outputs and the spatial industrial scientists in Nigeria. As observed in the surveys, only the physical surface and climatic essentials were in sufficient standards specifically at $57.1 \%$ and $64.3 \%$. By empirical implications in this regard, the physical surface is large enough to stimulate effective industrial establishment while the climatic essentials which prevail in suitably pristine sequence could facilitate the degrees of ambient and indoor comfort of the workers in the specific industrial workplaces in Nigeria.

The other significant industrial establishment factors as raw materials, working capital, technology, transportation, domestic labour, skilled management, workplace security, market performance, storage facilities and paid allowances as observed are inadequate in standards at $46.4 \%, 51.5 \%, 55.4 \%, 48.2 \%, 54.5 \%, 53.0 \%, 45.4 \%, 55.2 \%, 45.7 \%$ and $52.1 \%$. More so, the energy provision (45.5\%) to the four major heavy industrial zones for sustainable operations and satisfactory resultsoriented performance is grossly poor in transmission in Nigeria.

\begin{tabular}{|c|c|c|c|c|}
\hline S/N & Location Factors & Adequate & Inadequate & Poor \\
\hline 1 & Physical Surface & 640 & 298 & 182 \\
\hline 2 & Raw materials & 360 & 520 & 240 \\
\hline 3 & Working capital & 310 & 580 & 230 \\
\hline 4 & Technology & 272 & 620 & 228 \\
\hline 5 & Transportation & 294 & 540 & 286 \\
\hline 6 & Energy supply & 290 & 320 & 510 \\
\hline 7 & Domestic labour & 260 & 610 & 250 \\
\hline 8 & Skilled management & 276 & 594 & 250 \\
\hline 9 & Workplace security & 322 & 508 & 270 \\
\hline 10 & Market performance & 310 & 618 & 192 \\
\hline 11 & Storage facilities & 330 & 278 & 512 \\
\hline 12 & Climatic elements & 720 & 250 & 150 \\
\hline 13 & Paid Allowances & 236 & 584 & 300 \\
\hline
\end{tabular}

Table 1: Contemporary Factors of Industrial Establishment in Nigeria Source: Field Surveys, 2018 


\begin{tabular}{|c|c|c|c|c|}
\hline S/N & Location Factors & Adequate & Inadequate & Poor \\
\hline 1 & Physical Surface & 57.1 & 26.6 & 16.3 \\
\hline 2 & Raw materials & 32.1 & 46.4 & 42.1 \\
\hline 3 & Working capital & 27.7 & 51.8 & 20.5 \\
\hline 4 & Technology & 24.3 & 55.4 & 20.4 \\
\hline 5 & Transportation & 26.3 & 48.2 & 25.5 \\
\hline 6 & Energy supply & 25.9 & 28.6 & 45.5 \\
\hline 7 & Domestic labour & 32.2 & 54.5 & 22.3 \\
\hline 8 & Skilled management & 24.6 & 53.0 & 22.3 \\
\hline 9 & Workplace security & 28.8 & 45.4 & 25.9 \\
\hline 10 & Market performance & 27.7 & 55.2 & 17.1 \\
\hline 11 & Storage facilities & 29.5 & 24.8 & 45.7 \\
\hline 12 & Climatic elements & 64.3 & 22.3 & 13.4 \\
\hline 13 & Paid Allowances & 21.1 & 52.1 & 26.8 \\
\hline
\end{tabular}

Table 2: Industrial Establishment Factors in \% Assessment in Nigeria

Source: Field Surveys, 2018

Based on these assessments, it is clear that, the current industrial operations and performances in Nigeria compared with the standard results-oriented situations in the 1980s and the dawn of early 1990s are generally inadequate and virtually poor. Needless to examine the levels of environmental insecurity, brain-drift overseas, inadequate funding of viable projects, chaotic governance, nullity of economic plans, impacts of climate change, political corruption, human ineptitude in the workplaces and ethnic cleansing perpetuated by the Fulani herdsmen as they impinge industrial operations in the current dispensation in Nigeria.

\section{Forms of Environmental Degradation in the Four Major Industrial Zones in Nigeria}

\subsection{The Lagos-Abeokuta-Ibadan-Osogbo Industrial Zone}

The salient parts of the preceding analysis have proven the realistic presence of heavy manufacturing industries in this industrial zone in Nigeria. Based on their operations and manufactured outputs exhibited for utilization, there is no doubt that these heavy industries have encroached on the significant urban environmental resources such as land, water, and the atmosphere. In fact, these environmental resources are observed to have borne the adverse burdens of immensely degrading consequences which deserve scientific analyses.

As observed in the field, these heavy industries continually deposit huge industrial waste products on the surface and fertile agro-soils in the zone. These waste products include empty cans, broken bottles, expired engine oil and diesel, torn plastics and textiles, charred remains of motorcycles and automobiles and confectioneries. The presence of these waste products on the environment constitutes disgusting eyesore to visiting friends and foreign tourists to the industrial zone. The waste materials degrade the aesthetic benefits of the whole urban environment. They pollute the agro-soils thereby making the fertile surfaces useless for agricultural production. The waste deposits on the land have largely impeded smooth urban transportation and daily human traverse on the approved walkways.

The diverse water bodies in the industrial zone such as the ocean, rivers, lagoons, bays and streams have also been degraded of their natural consumption qualities and wildlife resources. Huge deposits of diverse waste materials and toxic chemical effluents have been discharged into these water bodies by the industries. The underground water has been impacted in this regard. The degradation which results to pollution of these water resources has led to the demise of large colonies of fish, crabs, crayfish, snails and animals. The previous studies carried out by scientists in this industrial zone have shown the presence of iron, manganese and mercury in the water samples beyond the World Health Organization's stipulated levels for drinking water across the world (Ayinla, 1985; Segynola, 1986).

In light of the contemporary surge in industrialization and inadequate management of industrial operations in the zone, we anticipate a higher increment of these toxic chemicals in the surrounding water bodies. In fact, some realistic areas of industrial water contamination specifically in the Lagos area are the Ijora-Eko waterways, Lawanson, Ebute-Ero, Apapa, Akoka-Yaba Lagoon, and parts of the Victoria and Lekki Beaches. The elaborate stench which emanates from these contaminated physical sites in modern day Lagos is adequate to cause instant typhoid within the pedestrians who frequently traverse the walkways

The continuous industrial operations have spurred atmospheric pollution in the industrial zone. As observed in the field, there are diverse industrial emissions of gases into the fresh urban atmosphere which are poorly managed in the industrial establishments. These gases include aerosol and chemical intertwined smog, carbon monoxide, sulphur dioxide and hydrogen sulphide. The recent upsurge in the statistics of motorcycles, vehicles and heavy-duty trailers in Lagos, Abeokuta, Ibadan and Osogbo have immensely exacerbated the poor state of atmospheric pollution in the zone. 


\subsection{The Benin-Sapele-Warri Industrial Zone}

In this significant industrial zone, there are many industrial establishments. Crude oil exploitation, gas processing and the refinement of liquid minerals into diverse petroleum products dominate the industrial zone. These operations are closely followed by the cut-down of forest trees and processing of same into useful electric poles, construction materials, furniture items and canoes. The African Timber and Plywood factory leads in the production of these resources in the zone. As observed in the reconnaissance surveys, this zone is an area of extensive crude oil exploitation where the fertile soils, vegetal and aquatic resources of immense values are damaged through crude oil spills and emissions of hot toxic gases. On this note, the fishermen, farmers, traders and the immediate communities suffer greatly owing to polluted water bodies which results to loss of quality water for drinking, important aquatic wildlife, fertile lands for food and cash crops production and agro-aquatic jobs for personal income generation. The destruction of suitable natural terrains for significant infrastructure constructions such as roads, buildings, health units, markets, schools, recreation spots, harbours, airports, train terminals and city squares were observed in the zone. Also found in the industrial zone are numerous death-trap ravines, bottomless crude oil waste filled pits and slippery marshy toxic swamps of dead wildlife.

There are other observed challenges of industrial degradation in the zone. These directly relate to deforestation and opening up of the natural surfaces for induced soil and wind erosions, massive waste generation and deposition on the virgin lands leading to decay of the live components of the lands, and destructive coastal erosion which results to river siltation that obstructs the smooth navigation of canoes, boats and cargo ships. Coastal erosion induced by careless acts of deforestation and exerted by rainfall and exacerbated by the surging sea waves has destroyed a number of physical facilities installed on the coastal environments in Nigeria. This zone is no exception in the current analysis of destructive coastal erosion.

\subsection{The Kaduna-Kano-Jos Industrial Zone}

This is the major industrial zone in the Northern part of Nigeria. It extends from Kaduna through Kano to Jos. In reality, this heavy industrial zone has a number of primary industries which are typically extractive and fabricative in operations. However, the processing of agro-produce into groundnut oil, hides and skins, diverse flour products and welldesigned textiles are truly rampant. These industries provide refined food for consistent human consumption, create meaningful jobs for the people and construct functional physical infrastructure on the plain surface for human utilization. Rampant incidents of environmental degradation are virtually non-existent in the sites of these industries.

The Kaduna refinery is the largest of all the heavy industries in the zone. Also, there are plastics, cutlery, textiles and power providing industries in the zone but the activities of these industrial units do not contribute to degradation which results to pollution of the huge environment. Except the once experienced Kaduna refinery crude oil spillage which was a product of inadvertent incident induced by the workers, such a case has not taken place in the contemporary epoch.

Our analysis of environmental degradation shifts to the Jos areas of tin and columbite extractions. In these areas, sands, rock fragments and minute particles of exploded in selberg-bearing minerals find their ways into the nearby streams and rivers thus rendering the water resources largely unfit for direct human consumption. In the industrial cities of Kaduna and Kano and related towns, the wastes created as textiles and agro-products are easily burnt in protective incinerators while others are processed into agro-fertilizers for seasonal farm operations. It is essential to observe that the environmental degradation induced by the industrial activities in this part of the zone is ecologically stable and relatively trifling in scope.

\subsection{The Onitsha-Enugu-Owerri-Port Harcourt Industrial Zone}

This significant industrial zone is habitat to a number of heavy manufacturing industries. As observed, the most dominant are the coal mining at Enugu, iron, steel and asbestos production in Owerri, Abakaliki and Port Harcourt, the crude oil, gas and petrochemical refinement in Port Harcourt and the plastic, textiles and agro-food processing factories in the four cities in the zone. The broad activities of these industries result to the same environmental degradations observed in the Benin-Sapele-Warri Zone. In brief, the coal mining activities in Enugu have contributed to extensive deforestation of the natural environment and mechanical excavations of the virgin lands thus resulting to grave soil denudation driven by torrential rains and gusty winds. The asbestos, iron and steel industries have persistently deposited huge sand particles and toxic chemical effluents into the nearby streams and rivers thus rendering the water resources unhealthy for regular wildlife habitation and human consumption. The pollution of the River Ekulu and others are realistic cases in this regard. More so, the refreshing urban atmosphere above these industries has also been contaminated by the diffused carbon monoxide, sulphur dioxide and aerosols produced and injected by the different industrial units in the zone. The sustained stench which emanates from these polluted surfaces can induce dangerous ailments on the people and living organisms found in the zone.

\section{Research Findings}

In respect of the analyses and overall assessment carried out in the study, the following findings are made.

First, the study observed the existence of widespread traditional industries and crafts in the pre-colonial Nigeria which utilized natural raw materials derived from the local environment for different consumable and non-consumable food items.

The study indicated that during the colonial period in Nigeria, industrialization was aimed at the valorization of export commodities which was a viable strategy meant to provide essential raw materials obtained from the natural environment and viable plantations for the organized British industrial economy. 
As Nigeria achieved fairly improved social, economic and stable political transformations in urban transportation, housing, health, communications, internet banking and marketing operations, four major industrial zones and some pockets of industrial establishments developed consequently in the country.

Of the four significant industrial zones which developed in Nigeria, the study observed that the Lagos-AbeokutaIbadan-Osogbo industrial zone was the largest heavy manufacturing sector. It contains a conglomeration of primary, secondary and tertiary industries which employ over $50 \%$ of the total Nigerian population in the contemporary epoch.

The study clearly indicates that the Benin-Sapele-Warri industrial zone constitutes of primary wood processing factories, different crude oil exploitation and refinement industries owned by the federal government, domestic and foreign business corporations, and a cross-section of operational miscellaneous industries.

Based on adequate land, raw materials, power, markets, skilled management, transport, capital and subsidized taxation, a suitably vast area of propulsive industries exists in the Sudan north-central of Northern Nigeria. Of these industrial varieties currently operational in the zone, the Kaduna refinery, the Kaduna-Kano textiles and the Jos tin and columbite industries are the largest with regard to size, outputs production, revenue generation, employment creation and infrastructure provisions.

The Onitsha-Enugu-Owerri-Port Harcourt industrial zone has a number of extractive, fabricative, crude oil refining and petrochemical industries. This zone combined with the Benin-Sapele-Warri industrial zone produces the best quality crude oil, fuel, kerosene, diesel, gas and chemicals which generate the highest local-foreign currencies for national deposition, accumulation, appropriation and utilization.

The study observed different forms of environmental degradation in the four major industrial zones in Nigeria. In the Lagos-Abeokuta-Ibadan-Osogbo industrial zone, the heavy industries were found to have recklessly encroached, through the deposition of solid, liquid and chemical waste products, on the urban indispensable environmental resources such as land, water and the atmosphere. The degradation resulted to extensive pollution of the landscapes and agro-soils, surface and underground drinking waters, air and abuse of the aesthetic values of the urban environment.

It observed vast destruction of fertile agricultural soils, vegetal, aquatic and atmospheric resources spurred by carelessly released crude oil spills and emissions of hot toxic gases, and the deforestation of the natural surface by the sawmills resulting to rain induced soil and wind erosions in the Benin-Sapele-Warri industrial zone. This made the fishermen, farmers, traders and the immediate communities suffer greatly owing to loss of quality water for drinking, aquatic wildlife for consumption, fertile soils for food and cash crops production and natural terrains for diverse infrastructure constructions. The study also found the existence of these forms of environmental degradation and associated impacts in the Onitsha-EnuguOwerri-Port Harcourt industrial zone in Nigeria.

The study observed the existence of poor industrial results in the areas of output production, job creations, infrastructure provisions, power generation, and income and foreign exchange attraction owing to the interaction of climate change and human-induced challenges.

Finally, the study observed the least environmental degradation in the Kaduna-Kano-Jos industrial zone. Specifically, in the Jos tin and columbite extraction areas, huge sands, rock fragments and exposed minute particles of exploded inselbergbearing minerals find their ways into the nearby streams and rivers thus rendering the waters largely unfit for direct wildlife and human consumption.

\section{Policy Recommendations}

Based on the findings of the study, the following policy recommendations are made. First, a viably stable industrial environment should be created and sustained in Nigeria. This propulsive industrial stability requires the provision of all the fundamental industrial necessities which include suitable environment, adequate working funds and durable capital, pristine climate-resistant technology, participatory markets, effective transportation systems, adequate raw materials, skilled labour and proficient management. The financial weights of the federal and state governments must be exerted to empower and sustain these laudable measures in Nigeria.

Second, the industrial diffusion approach and even spacing techniques based on sound economic resources of the new industrial sites using update political maps of states and local government areas are required to bridge the vacuums in the disproportional industrial landscapes observed in the country. On this note, it is essential for the Nigerian federal and state governments to establish twelve new large-scale manufacturing industrial zones with three large-scale industries each in the coastal, forest, middle belt and the northern regions. The indispensable roles of the industrial geographers, cartographers, remote sensing scientists, economists, and the practising industrialists are needed in this regard to succeed.

Standard social, economic and political transformations with reference to rural and urban transport systems, viable housing, health, recreations, communications, internet banking and marketing operations, investment stability, environmental and human security and stable monetary values should be expedited and sustained in Nigeria. These significant factors in sustained harmony with the industrial establishment requirements itemized would help strengthen the viability of the Nigerian industries in the contemporary epoch and beyond. Specifically, new hospitals and health care units equipped with modern operational tools and instruments and deployed with specialists in different fields of medicine must be established to cater for the health needs of the immediate communities and workers in the polluted industrial zones in Nigeria. This panacea signifies that vibrant human health begets adequate industrial production. 
There should be mandatorily efficient field explorations and selective exploitation of domestic raw materials for industrial utilization in Nigeria. These measures would help adhere strictly to standard global ecological principles which encourage beneficial field surveys and acquisition of essential raw materials ridden of deforestation, vast surface openings, random ravine formations and persistent deposition of hazardous waste products on the environment. While improved industrialization which produces adequate outputs, revenues, jobs and creates viable infrastructures for the people's satisfaction would be witnessed on the one side of the industrial landscape, beneficial environmental purity which promotes lively human habitation, comfort and healthy life would be experienced on the other angle in Nigeria.

A pragmatically consistent daily environmental sanitation should be conceived and expedited in the four major industrial zones and pockets of industrial establishments in Nigeria. This daily sanitation should be complemented with a comprehensive monthly environmental clearance of all types of waste products from the physical surfaces and other beneath environments. These measures would eradicate the daily obstructions of the smooth transportation of humans, goods, services and other strategic resources across the physical surfaces in the country.

Broad scientific surveys, identifications and authentic assessments of all the degraded and polluted environmental resources such as the ponds, streams and rivers, fertile soil surfaces, farmlands, physical surfaces, vegetations and atmosphere should be carried out by environmental experts in the four major heavy manufacturing industrial zones in the country. These measures would create the suitable climates for comprehensive scientific treatments of these resources with a positive view to transforming them into genuinely new environmental resources necessary for domestic, state and national utilizations. More so, all the activities which contribute to waste generation and dissemination on the environment must be avoided by the urban industrialists and residents in the specific industrial zones. To crown it all, currently viable and computerized pollution control, prevention, mitigation and abatement technologies should be acquired and installed in the four major industrial zones and the newly proposed twelve additional zones in Nigeria.

As observed in the study, $\mathrm{CO}_{2}$ is one of the most frequently emitted greenhouse gases into the Nigerian environment. Its production, emission and concentration in the atmosphere should be regulated and stabilized using the most recently devised technologies by the western scientists. The use of carbon sinks, carbon capture and storage are recommended as a first measure. A carbon sink refers to a natural or artificial reservoir which accumulates and stores some carbons containing chemical compounds for an indefinite period. Some suitable storage locations in this consideration include the subterranean geologic formations, the seas and oceans and some specifically designated water bodies and the forests. The carbon capture and storage are a technique devised to mitigate climate change by capturing $\mathrm{CO}_{2}$ from large point sources and carefully storing it away in secured enclosures instead of releasing it into the environment. Above all, high carbon emission intensity industries and power sources should be replaced with very low carbon producing industries and energy sources. To this end, the provision of electricity by renewable energy sources should be encouraged in the NIL and these would deliver the largest proportional carbon reductions required in this situation. Of course, the NIL must adhere to these fruitful industrial principles in time without procrastination.

Significantly, all the industrial activities in Nigeria should be carried out in complete harmony with environmental decency and human comfort. This implies that successfully thorough environmental impact assessments must precede the location and establishment of industries in the country where the overall gains and challenges of the proposed industrial units can be analyzed and understood by the industrialists, the government, the private sector, the immediate communities and all the stakeholders. While effective industrial waste clearance and disposal methods with successful waste treatments are advocated in the study, it also suggests the incorporation of extensive recovery of spilled crude oils from the lands and water bodies by some specialist industries reputable for technical integrity and infallible workplace experiences.

The study suggests strict adherence to industrial dispersal approach which would reduce the heavy concentration of industries, industrial wastes and associated reckless diffusion on the four major industrial zones including the contiguous landscapes, vegetal and water surfaces. This approach would also result to proportional diffusion of socio-economic development in Nigeria. Efficacious waste control, clearance, treatment and disposal on the environment require the concerted efforts of the public and private sectors to succeed in Nigeria. On this vital note, the Nigerian government must legislate on the issues of urban industrial waste generation, clearance, treatment and disposal. Therefore, the erring industrial units in this regard must be sanctioned accordingly to operational enacted legislations.

In order to establish and ensure a vibrantly productive heavy manufacturing industrial economy which competes favourably with the industrial economies of the developed western world in Nigeria, a competent, expert-driven, corruption and ineptitude-ridden, ethnic-immune and technologically spurred national government must be instituted by the people through a fair, credible, and sustained democratic process. More so, the instituted government must be proficiently receptive to constructive criticisms offered by the best brains within the country and beyond its international frontiers. These measures would be used to make the necessary changes in the industrial economy for sustained production in Nigeria.

The overall success of these measures rests on political stability, secure workplace environment and authentic governance of Nigeria by the educated patriots-elect. The supply of suitable raw materials, adequate funds and stable energy to the diverse industrial units and utilization of digital technologies in the industrial workplaces are most necessary in this regard. Effective management of all the industrial activities to ensure maximum production of outputs in time is mandatory. In addition, a change from the corrupt and ineptitude traits of workers to refined and authentic management qualities in the various industrial units in Nigeria is a necessity. 
The realistic implications of these policy measures would be largely appreciated by the people in proportionally ameliorated socio-economic environments, beneficially transformed agricultural soils for adequate food and cash crops production, adequately clean and safe drinking waters from the surface and underground water resources, radiating fresh breezes from the dynamic urban troposphere and relatively healthy rural-urban environments for massive results-oriented industrial operations and comfortable human habitation in Nigeria.

\section{Summary and Conclusion}

This study has examined the Nigerian Industrial Landscape and Environmental Degradation. Its focus was on the sequential evolution of the four major industrial zones using the spatio-temporal approach and cause-effect analysis in Nigeria. The study observed the vital roles of the Nigerian industries in the refinement of raw materials into diverse utilities, creation of jobs, generation of revenues and construction of beneficial socio-economic facilities on the physical environment. Insecure workplace environments, drift of specialists overseas, inadequate funding, poor technology, insufficient raw materials, epileptic power transmission, deficient transport and communications, inter-alia, were observed as the challenges on effective industrial operations in Nigeria. The analyses of the Nigerian Industrial Landscape revealed grave environmental degradation and pollution in the three major industrial zones with reduced intensity in the Kaduna-Kano-Jos Triangle. Based on the research findings, the study suggests, inter-alia, the provision of suitable raw materials, adequate funds, viable digital technologies, stable energy, robust transport and communications, and secure workplace environments to ensure sustained large-scale industrial operations in Nigeria. Above all, the study recommends adequate industrial wastes control, treatment and disposal and specialist clearance of crude oil spills and mining wastes from the land, vegetal and water surfaces to stem the fierce tides of industrial degradation and pollution of the Nigerian environment.

\section{References}

i. Adeboye, T.0. (1981). Nigerian industrialization: A reconsideration of strategy and policy options. Research for Development. 1 (1). 53-68.

ii. Adegbola, K. (1978). Manufacturing industries. In Oguntoyinbo, J.S. (Ed.), A Geography of Nigerian Development. Ibadan: Heinemann Nig. Ltd. 291-394.

iii. Akinbode, A. (2004). Prospects for geography and geographers in the 21st Century: valedictory essays. Department of Geography and Regional Planning, Ambrose Alli University, Ekpoma, Nigeria. 20-21.

iv. Ayinla, P. (Daily Times, 1985. pp. 16). Protecting the environment from industrial pollution. Lagos.

v. Collins, B. (2010). Collins senior secondary atlas for Nigeria. London: Harper Collins Publishers. 17.

vi. Obot, J.U. (1978). Industrial development planning and environmental pollution: the case of Calabar municipality, Nigeria. Paper presented at the national conference of development and the environment, NISER, Ibadan. 4-6.

vii. Okafor, F.C. (1983). Rural industrialization and spatial equity: an assessment of Nigeria's industrial policy. Paper presented at the national conference on industrial development policy in Nigeria, University of Ife, Nigeria. 6-7.

viii. Okhakhu, P.A. (2016). Rural development and environmental protection in Nigeria. Developing Country Studies. 6 (1). 131-138.

ix. Omuta, G.E.D. (1984). Rural industrialization and environmental degradation. The case of Bendel cement company, Okpella, Bendel State. Department of Geography and Regional Planning, University of Benin, Benin City, Nigeria. 5-6.

x. Oyebanji, J.O. (1982). Manufacturing under-development: The Nigerian experience", Paper presented at the 25th Annual Conference of the Nigerian Geographical Association, University of Ibadan, Nigeria. 6.

xi. Sada, P.O. (1984). Urban households and housing conditions in Nigerian cities with special reference to Warri and Benin. In Sada, P.O. and Osirike, A.B. (Eds.), Case Studies in Urbanization in Nigeria: Perspectives in Policy Issues, Benin City, Nigeria. 118-131.

xii. Segynola, A.A. (1986). The Nigerian industrial landscape and environmental degradation. In Sada, P.O. and Odemerho, F.O. (Eds.), Environmental Issues and Management in Nigerian Development. Ibadan: Evans Brothers Ltd. 174-181.

xiii. Segynola, A.A. (2010). Industrialization and analytical techniques: postgraduate lecture notes. Department of Geography and Regional Planning, Ambrose Alli University, Ekpoma, Nigeria. 1-2.

xiv. Sullivan, B.C. and Ikpeze, N. (1980). Problems of industrial growth in Nigeria. In Amucheazi, E.C. (Ed.), Readings in Social Sciences: Issues in National Development. Enugu: Fourth Dimension Pub. Co. Ltd. 51-66. 